\title{
Women's Economic Empowerment through Micro-credit program: A Case of Thengamara Mohila Sabuj Sangha (TMSS) in Rural Bangladesh
}

\author{
MD. MAHBUBUR RAHMAN* \\ KAZI SHAHDAT KABIR** \\ MD. ABDULLAH AL HELAL ${ }^{* * *}$
}

\section{ABSTRACT}

The paper is an endeavor to assess women's economic empowerment through micro-credit program by evaluating different activities in various economic spheres in the rural area of Bangladesh. The study has been done utilizing both quantitative and qualitative methods. Using role of women in different economic spheres like household level, community level and broader arenas, a survey questionnaire was designed to collect data from 152 women following snow-ball sampling procedure and different statistical methods were applied to analyze the collected data. In addition, qualitative techniques like FGD and case study were used to validate the analyzed data. Finally, applying multiple regression method, the study revealed that different factors of household and community level e.g. ability of establishing rural cooperative banks, control of own poultry farm and its utilization, control of own jewelry and enjoyment, decision-making in land or equipment selling in an emergency and independent savings have been found significantly associated with the women's economic empowerment in the studied area.

Key words: Economic empowerment, TMSS, Micro-credit, Household and social resources, Productive and nonproductive assets, Farm and non-farm activities.

\section{INTRODUCTION}

Life for women in rural Bangladesh is heavily circumscribed by both the prevailing patriarchal system and religious edict. Their presence at the market is

* Senior Lecturer in General Education Department or GED (Anthropology), Northern University Bangladesh, Dhaka.

* Associate Professor, Department of Governance Studies, Northern University Bangladesh, Dhaka.

${ }^{* * *}$ Senior Lecturer in General Education Department or GED (Social Work), Northern University Bangladesh, Dhaka. 
forbidden and they are also not supposed to handle money, or exercise property rights, all of which severely restricts potential economic activities and choices leaving them subordinate and dependant on men. Bangladesh is a least developing country where women constitute almost half of its total population of which $80 \%$ live in rural areas (BBS, 2006). Traditionally women in Bangladesh have lower status as compared to men in every sphere of socio-economic and political life and they have very limited access to income generating activities due to a number of social, cultural and religious obstacles.

Globally, in 2011, 384 million workers were living below the poverty line earning $\$ 1.25$ a day while the gender gap in employment persisted with a 24.8 percentage point difference between men and women in the employment-topopulation ratio in 2012 (MDG, 2013). According to the World Bank's gender statistics database, women have a higher unemployment rate than men in virtually every country (worldbank.org). In general, women also make up the majority of the lower paid, unorganized informal sector of most economies.

TMSS (Thengamara Mohila Sabuj Sangha) is a woman, children and gender development Program which specially emphasized on Mohila's (woman) empowerment through microcredit system. The activities of TMSS revolve around capacity improvement of women so that they can participate in decisionmaking process to mitigate their poverty. The predominant image of empowerment in development is that of women gaining (material) means to empower themselves as individuals, and putting this to the service of their families and communities. This is primarily because empowerment is understood in relation to deliberate and planned interventions such as electoral quotas, education, economic empowerment initiatives, legislative change and nongovernmental public action. TMSS is working in this regard since 1980s. So the study is rated as essential to find out the real scenario of the level of women's economic empowerment through microcredit.

\section{OBJECTIVES OF THE STUDY}

In terms of a broad objective the present study is largely focused on women's economic empowerment through microcredit program of TMSS in the rural Bangladesh. The specific objectives are:

i. To delineate the socio-economic profile of the respondents;

ii. To measure the access of women's to household and social resources;

iii. To analyze women's participation in farm and non-farm activities; 
iv. To find out women's ownership of productive and nonproductive assets;

v. To estimate the determinants of women's decision-making on economic issues.

\section{LITERATURE REVIEW}

It has often been postulated that if women had opportunities for gainful work outside the household, this would render their contributions to the household more visible, and concurrently reduce their economic dependence on their husbands (Kamal, et al., 1992). In fact "money going through a woman in a household [brings] more benefits to the household than money entering the household through a man" (Yunus, 1991).

Some studies showed the significant positive correlations between micro credit and women's economic, political, socio-cultural and interpersonal empowerment. Shahnaj Parveen and Ingrid-Ute Leonhäuser (2004) showed that empowerment criteria indicates that $83 \%$ of the women have a very low to economic contribution, $44 \%$ have a very low access to resources, 93\% have a very poor to poor asset ownership, $73 \%$ have a moderate to high participation in household decision-making, $43 \%$ have a highly unfavorable to unfavorable perception on gender awareness and $72 \%$ have a moderate to high coping capacity to household shocks. The multiple regression analysis shows that there were strong positive effects of formal and non-formal education, information media exposure and spatial mobility on women's CEI, while traditional sociocultural norms have a strong negative effect. Moreover Pitt, Mark M. et al. (1996) found out credit program participation leads to women taking a greater role in household decision-making, having greater access to financial and economic resources, having greater social networks, having greater bargaining power compared with their husbands, and having greater freedom of mobility. Moreover, though credit program members do not contribute independently because their husbands mostly utilize their loan funds, the loans they have taken are not generating income, or for various other reasons, just the experience of being a member of the program is beneficial for empowerment (Hashemi et al.1996). Some studies showed the comparison of the level of empowerment between the credit and without credit. The findings show that majority (84\%) of the 'with credit' respondents is more empowered in terms of family decision making matters compared to the 'without credit' (76\%) respondent. It is concluded that 'with credit' rural women have enhanced their empowerment by participating in microcredit programs of Grameen Bank Bangladesh (Ferdoushi Ahmed et al.). Self-income generating activities by entrepreneurship are the most 
important contributing factor to empowering rural women in Bangladesh (Md. Rafiqul Islam 2011).

Studies, however, show some negative impacts of microfinance on women. Goetz and Gupta (1996) have proved that because of pressure for enforcement of loan contracts, women have to reduce necessary household basic needs, savings to repay the loans in case men invest badly, or are not willing to give money for repayment. Consequently, women's lost control over credit has reinforced gender norms and exacerbated the welfare of women and households. Some studies even suggest that women are abused by microcredit to reduce transaction costs, thus increasing the burden for women, deepening frustration and tension among household members and in women's groups (Rahman, 1999, Kabeer, 2001). In addition to, there is little evidence of radical change in the gender division of labor resulting from women's access to loan as women are still doing traditional home-based jobs like poultry raising, tailoring, paddy husking (Kabeer, 2001). Besides Aminul Faraizi et al. (2010) have noted the success of microcredit as well as the critiques of it in the context of women's empowerment. The book goes on to establish that the well-publicized success stories of the microcredit program are blown out of proportion, and that the dynamics of collective responsibility for repayment of loans by a group of women borrowers - usually seen to be a tool for the success of microcredit - is in fact no less repressive than traditional debt collectors.

\section{METHODOLOGY, DATA COLLECTION AND LIMITATIONS OF THE STUDY}

It is not possible to cover the data collection by one single method or technique for such a study. Hence, both qualitative and quantitative techniques such as structured questionnaire, having open-ended and closed questionnaire survey, in-depth interview, case study method and Focus Group Discussion (FGD) have been utilized. The data have been collected from the three different villages, because all microcredit borrowers did not receive money from TMSS. Few borrowers have received loan from Grameen Bank and others from BRAC and ASA. In this regard, sampling design was followed by "snow ball sampling method". At first the researchers have selected the group leaders who have received loan from TMSS of a particular area. Then according to information given by the group leaders, the researchers have recognized the other respondents of the studied area. The study has randomly selected 152 respondents from the three different villages of Bogra district of Sadar Upazila. The period of data collection was from August 05 to October 22 in 2012.Simple descriptive statistics such as sums, means, percentages, frequency distributions and cross 
tabulations were used to analyze primary data for this study. This study utilized the Statistical Package for Social Science (SPSS) 16 version to analyze the data. The foremost limitation of the study is associated with the sample size of the studied area. One hundred and fifty-two respondents might not be enough to generalize the findings comparing to other parts of Bogra and the greater Bangladesh

\subsection{Model}

The authors have used women's economic empowerment as the dependent variable whereas access of household level activities, community and national level activities have been considered as the independent variable. Thus the basic model for the study was therefore as follows:

$$
\mathrm{W} E_{\mathrm{a}} E_{m}=\alpha+\beta_{1} X_{H H 1}+\beta_{2} X_{H H 2}+\beta_{3} X_{H H a}+\beta_{4} X_{C m 1}+\beta_{5} X_{C m 2}+e
$$

Where,

$$
\begin{aligned}
& \mathrm{W} E_{c} E_{m}=\text { Index of Women's Economic Empowerment } \\
& X_{H H}=\text { Household level of variables } \\
& X_{H H 1}=\text { Household and Social resources } \\
& X_{H H 2}=\text { Farm and nonfarm activities } \\
& X_{H H 3}=\text { Productive and non-productive assets } \\
& X_{C m}=\text { Community level variables } \\
& X_{C M 1}=\text { Equitable consumption, money utilization and scope of } \\
& \quad \text { education } \\
& X_{C M 2}=\text { Decisions upon economic issues } \\
& e=\text { error term }
\end{aligned}
$$

Where $\alpha$ is constant and $\beta_{1}, \beta_{2}, \beta_{5}, \beta_{4}, \beta_{5}$ are coefficients to estimate, and $e$ is the error term.

\subsection{Analytical Framework}

Several different efforts have been made in recent years to develop comprehensive frameworks delineating the various dimensions through which women can be economically empowered. Here we are presenting the essential elements of the empowerment frameworks developed by different authors and organizations. The framework showed three different dimensions within each dimension, there is a range of sub-domains upon which women may be empowered. In order to operationalize these dimensions, one should consider indicators at various levels of social aggregation -- the household, community, as 
well as national levels. In Figure 01, we have grouped commonly used and potentially useful indicators within various "arenas" or spheres of life.

FIGURE 01: Integrated Framework of Economic Empowerment

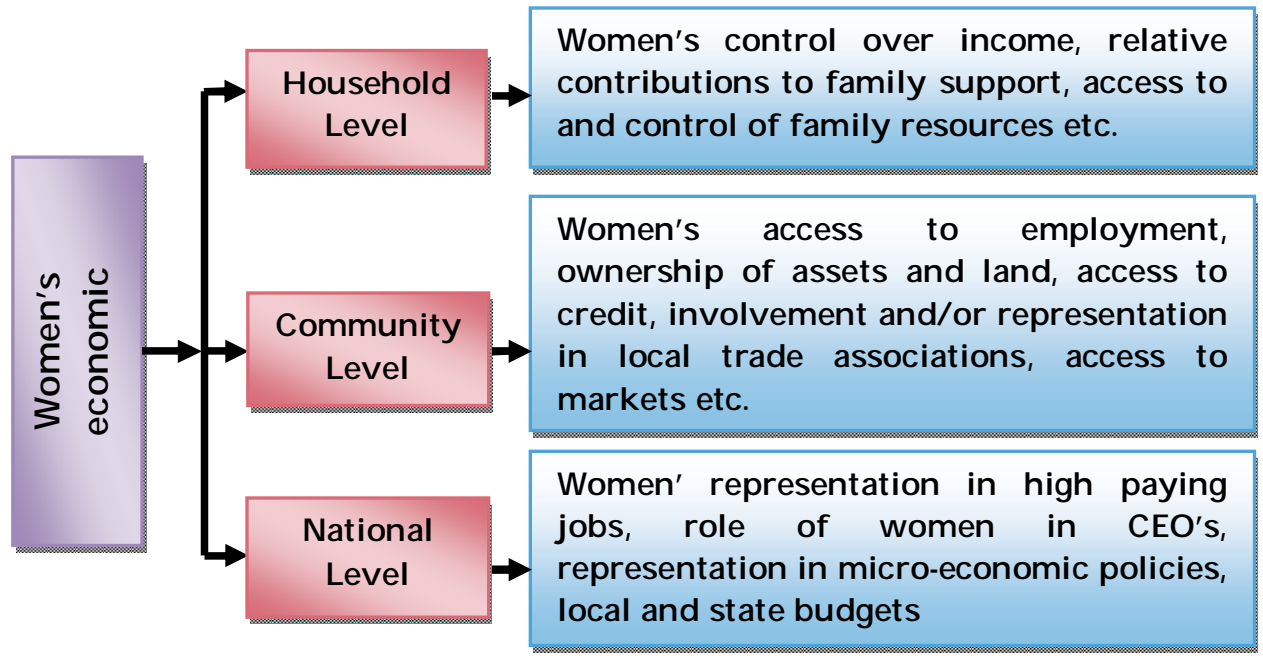

\section{EMPIRICAL FINDINGS AND ANALYSIS}

Socio-economic characteristics of the Respondents: The socio- economic factors indicate different variables such as age, gender, occupation, monthly income, religion and level of education etc. As the nature of study indicates only female respondents in terms of gender, so it doesn't need to mention the percentage at the figure independently.

FIGURE 02: Age of the Respondents

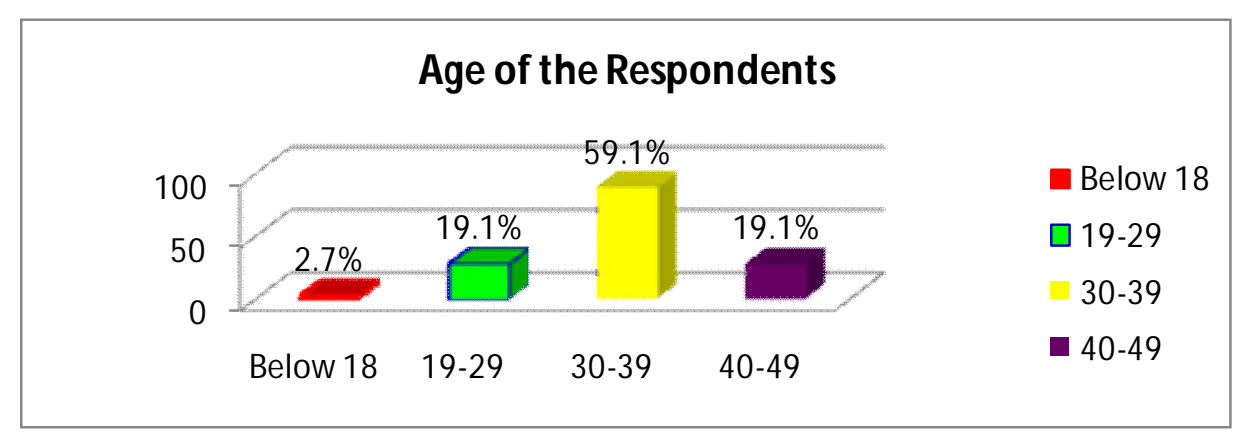

Source: Field Survey, August- October, 2012 
The above-mentioned figure showed that the range of the age group was from 'below 18' to 'above 50' where the age group ' 30 to 39' belonged to the highest (59.1\%) respondents. Followed by the age group of '20-29' and '40-49' respectively (their share being $19.1 \%$ for each). Generally the age group of ' 30 to 39' represents highly competitive people in terms of physical and mental strength. They are more likely to take the challenges to meet economic solvency. The elderly also tend to be more reluctant to receive the loan.

FIGURE 03:Monthly Income(Taka) of the Respondents

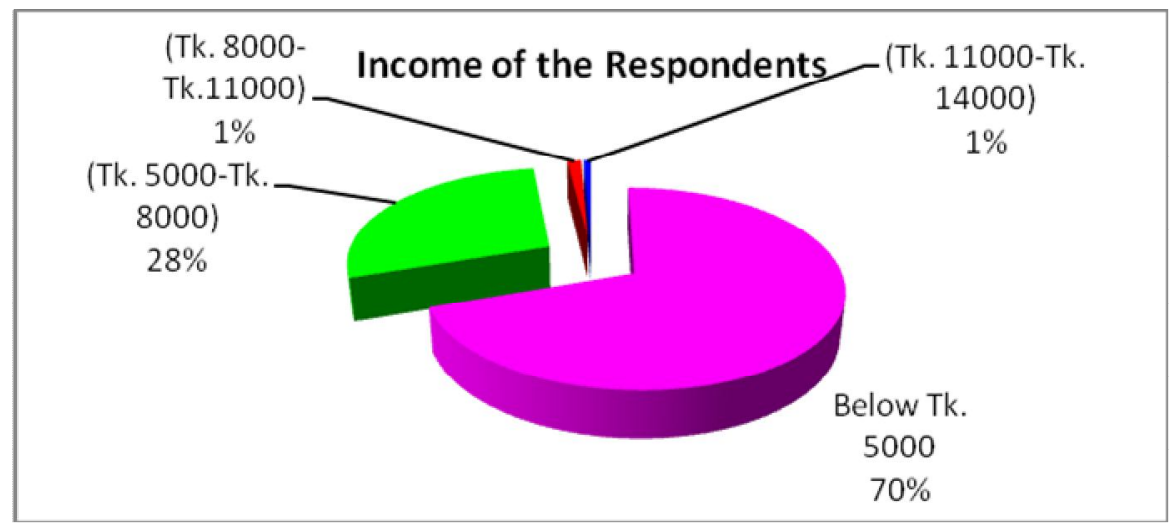

Source: Field Survey, August- October, 2012

The study found that majority of the respondents income $(69.7 \%)$ was below Tk. 5000. Only $1 \%$ of the respondents' income was between Tk. 8,000 to Tk. 11,000 and Tk. 10,000 to Tk.14, 000 respectively, whereas income level Tk.5,000 to Tk.8,000 belonged to rest of the $28 \%$ respondents' income. 
FIGURE 04: Level of Education of the Respondents

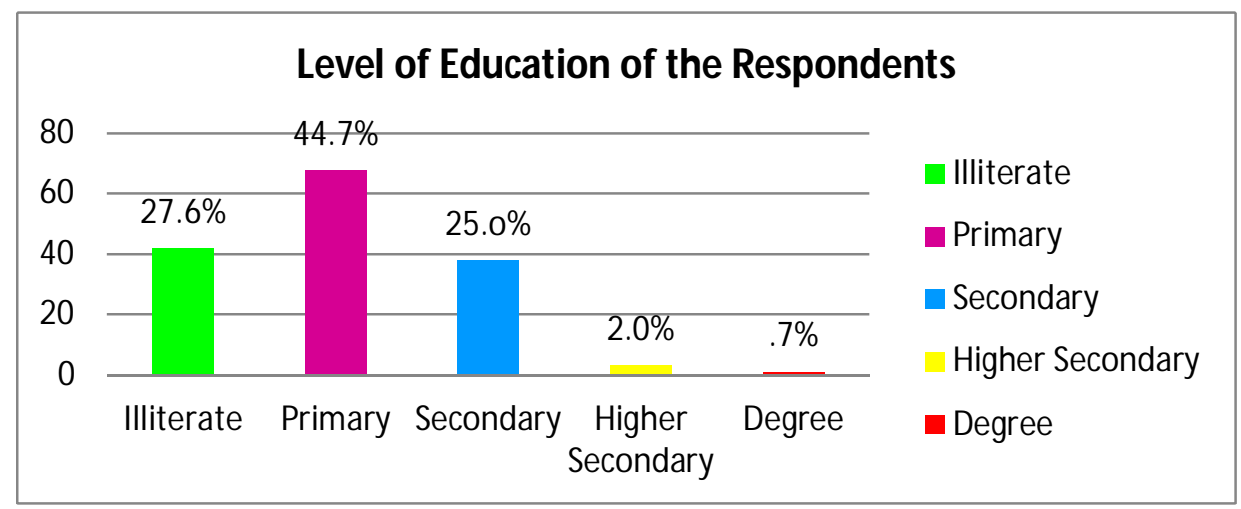

Source: Field Survey, August- October, 2012

The study illustrated maximum $44.7 \%$ respondents have completed only primary level of education followed by $27.6 \%$ were illiterate, they don't know even how to read and write. And $25 \%$ respondents have passed secondary level whereas only $2 \%$ and $1 \%$ of respondents' education level were with higher secondary and degree level of education respectively.

FIGURE 05: Occupation of the Respondents

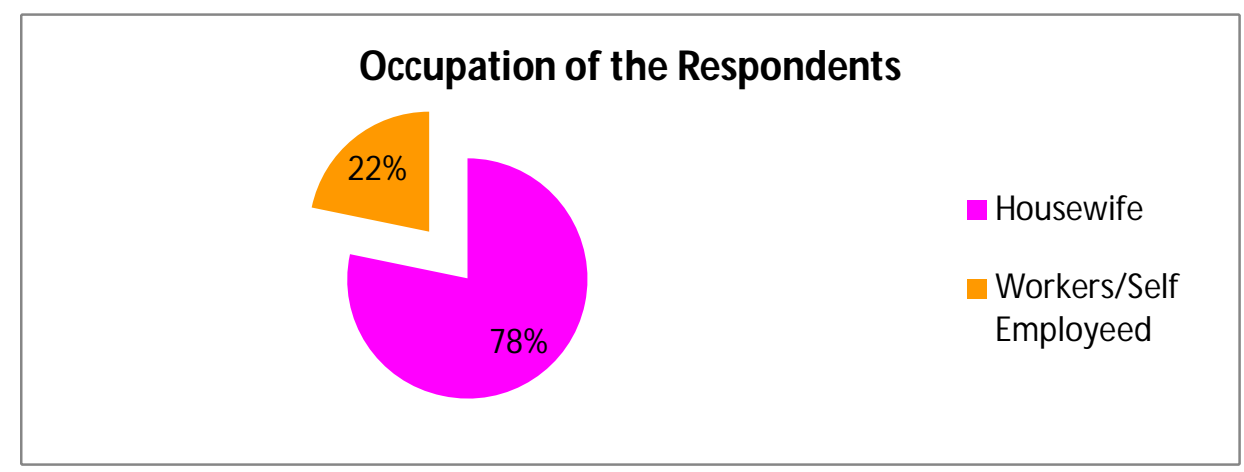

Source: Field Survey, August-October, 2012

In terms of occupation, most of the respondents were housewife accounting for $78 \%$ followed by the worker at different private institutions or self-employed are only $22 \%$. Observing the data on religion maximum (97.4\%) respondents were Muslims and the rest of respondents were from Hindu community. 
Women's economic empowerment through access of household and social resources:

The annex Table 01 revealed that most of the women have little access to spend from their own income whereas very few of them $(15.8 \%)$ have full access. Very few of them have the capacity to maintain their family expenditure and spend on income of husband and son. On the issue of budgeting of the family, maximum women have small capacity. Only few women can freely move for shopping and marketing, whereas 5.3\% don't have any access. Most of the women have little access to buy their children's dress. Half of the respondents have full access to purchase necessary groceries. In respect of buying own dress or ornaments without consulting husband most of the women have little access while $27 \%$ have no access.

Women's economic empowerment through farm and non-farm activities and of the ownership of productive and non-productive assets:

Almost half of the women have access to land and seedbed preparation, sowing planting and transplantation. Moreover, maximum of them have full access in harvesting and threshing crops, as well as drying and preservation of straws. Most of the respondents extensively participate of homestead cultivation and livestock rearing activities. A large number of respondents fully participate at poultry rearing activities while very few of them of fishing culture. But remarkably, only $47.2 \%$ women take part in handicraft production activities (in the Annex Table 02). The Annex Table 03 showed only $36.2 \%$ women have control of ownership on own land as well they can enjoy little over it. In addition, they have little control on their own cattle or goat. Regarding the variables of control over own poultry or cash savings and enjoy and own jewelry and enjoy, $40.8 \%$ and $34.2 \%$ respondents have control over these respectively. Very few women have control on their own television or radio as well as small vehicles.

Women's economic empowerment in terms of equitable consumption, money utilization and scope of education:

The Annex Table 04 revealed that only very few women have high access on handling and spending money while $14.5 \%$ have no access. Only a few women have high access on selling of minor expenditure while $44.1 \%$ have no access. Almost half of the women have the access of equal consumption of foods while $7.9 \%$ have no access in the family. Only $27.6 \%$ women have little scope of hiring 
and helping hands whereas $15.8 \%$ have no access. Most importantly, only $4.6 \%$ women can utilize the borrowed money for their own needs and education purpose. Concerning the factors rural cooperative and bank, very few have high access while $14.5 \%$ women have no access.

Dynamics of Women's economic empowerment through decisions regarding economic issues:

Most of the women have independent savings while majority (63.8\%)of them can't manage emergency fund. Maximum women responded that their husbands alone take decisions on spending and land or equipment decision, while only $18.4 \%$ women take part on that issue. Concerning the factors of land or equipment implementation and spending, only few of them can do it. Regarding the factors of fund access from asset sale, from husband and husband's relatives, only $19.7 \%, 32.9 \%$ and $27.6 \%$ respondents can manage respectively. Conversely, about half of the women access fund from their own relatives while $34.9 \%$ from money lenders and $23.7 \%$ from other people (in the Annex Table 05)

Correlation analysis between socio-economic factors and women's economic empowerment:

In the Annex Table 06 illustrated that women empowerment is significantly related with different socio-economic factors such as age $(\mathrm{p}<0.01 \%)$, occupation $(\mathrm{p}<0.01 \%)$, income $(\mathrm{p}<0.01 \%)$, education $(\mathrm{p}<0.01 \%)$, religion $(\mathrm{P}<0.01 \%)$. Moreover, in the Annex Table 07 elucidated that few factors such as, freely moving for shopping, decision on children dress, small purchase and large purchase, as well as maintenance of family expenditure were to be found significantly related with women's economic empowerment. The Table found shopping freely $(\mathrm{p}<.01)$, children dress $(\mathrm{p}<.05)$, large purchase $(\mathrm{p}<.01)$, maintenance of family expenditure $(\mathrm{p}<.05)$. In this sense, an FGD participant stated:

Being member of TMSS microcredit program, my status has been improved in terms of activities of household and social issues. Earlier I couldn't get to easy access at shopping due to unavailability of earning sources, but now I can buy my own dress as well as children's. My husband shares every thing on large purchases and expenditures. But in contrast to other factors i.e. children's education, spending on husband's and son's income and my own dress or ornaments, I have little 
contribution without consulting my husband. (35 years old, Jamila Khatun, Field Work, 2012).

In the Annex Table 08 explained that few factors of farm and non-farm activities are strongly correlated with the women's economic empowerment. Among the dynamics, land and seedbed preparation, sowing planting transplanting, harvesting and threshing crops, drying and preservation of straws, livestock rearing, poultry rearing, fish culture, business and handicraft production are found to be significantly related with women's economic empowerment. The above table found that land and seedbed preparation $(\mathrm{p}<.01)$, sowing planting transplanting $(\mathrm{p}<.01)$, harvesting and threshing crops $(\mathrm{p}<.01)$, drying and preservation of straws $(p<.01)$, livestock rearing $(p<.05)$, fish culture $(p<.01)$, Poultry rearing $(\mathrm{p}<.01)$, business and handicraft production $(\mathrm{p}<.01)$. In this connection an FGD participant stated:

We have very small pieces of land and thus my husband took lease when I borrowed an amount of 20,000 take from TMSS. Then we yielded varieties of crops i.e. paddy, wheat and others seasonal crops. Basically, I participate in all the activities related to agriculture e.g. crops harvesting, drying and preservations of straws, livestock and poultry rearing etc. (Rebeka Khatun, 40 years old, Fieldwork, 2012)

Annex Table 09 described that few activities such as, equal consumption, handling and spending money, selling of minor agricultural products, scope of utilization of credited money, scope of education, scope of rural cooperative bank have found to be strongly associated watch women's economic empowerment. The table showed equal consumption $(\mathrm{p}<.01)$ handling and spending money $(\mathrm{p}<.01)$, selling of minor agricultural products $(\mathrm{p}<.01)$, selling of minor agricultural products $(\mathrm{p}<.01)$, scope utilization of credit money $(\mathrm{p}<.01)$, scope of education $(\mathrm{p}<.01)$, scope rural cooperative bank $(\mathrm{p}<.01)$. Moreover, control own land and enjoy $(\mathrm{p}<.01)$, control own cattle and goat and enjoy $(\mathrm{p}<.01)$, control own poultry or cash savings and enjoy $(\mathrm{p}<.01)$, control own jewelry and enjoy $(\mathrm{p}<.01)$ have found significantly correlated with the economic empowerment.

Annex Table 10 explained that the following few factors about decisions on economic issues have found substantively correlated with women's economic empowerment. These are household loans expending, land or equipment decision, land or equipment implementation, land o $\mathrm{r}$ equipment spending, independent saving, emergency fund expense, fund access by assets sale, access from husband, fund access from husband relatives, fund access from own relatives, fund access from money lenders, fund access from other people. The 
table illustrated the significant values regarding the following factors such as household loans expending ( $\mathrm{p}<.01)$, land or equipment decision $(\mathrm{p}<.01)$, land or equipment implementation $(\mathrm{p}<.01)$, land or equipment spending $(\mathrm{p}<.01)$, independent saving and control of wife $(p<.01)$, emergency fund expense $(\mathrm{p}<.01)$, fund access by assets sale $(\mathrm{p}<.01)$, access from husband $(\mathrm{p}<.01)$, fund access from husband relatives $(p<.01)$, fund access from own relatives $(p<.01)$, fund access from money lenders $(\mathrm{p}<.01)$, fund access from other people $(\mathrm{p}<.01)$.

\section{TABLE 01}

REGRESSION MODEL

\begin{tabular}{|c|l|c|c|c|l|l|}
\hline Model & $\mathrm{R}$ & $\mathrm{R}$ Square & $\begin{array}{c}\text { Adjusted R } \\
\text { Square }\end{array}$ & $\begin{array}{c}\text { Std. Error of } \\
\text { the Estimate }\end{array}$ & $\mathrm{F}$ & Sig. \\
\hline 1 & $.958^{\mathrm{a}}$ & .918 & .892 & .22262 & 35.741 & 0.000 \\
\hline
\end{tabular}

Source: Field Survey, August- October, 2012

See the above regression analysis, it illustrates that there is a significance of regression equation between dependent variable (women's economic empowerment) and independent (Household level, Community level and National level activities) variables. And at $1 \%$ level of significance the correlation is $95.80 \%$. Here adjusted $\mathrm{R}$ square is 0.892 which means that about $89 \%$ variation of dependent variable is elucidated by independent variables in the model.

\section{TABLE 02}

\section{RESULTS OF MULTIPLE REGRESSION}

Women's Economic Empowerment (Dependent Variable), Household, Community Level and National Level Activities (Independent Variables).

Coefficient analysis showed the relationship between dependent variable (economic empowerment) and independent variables. It is matter of fact that the independent variables which have been statistically significant with the Cramer's $\mathrm{V}$ and Phi values (1\% level of significance) were taken under consideration at multiple regression analysis. 
TABLE 02 (Contd.)

\begin{tabular}{|c|c|c|c|c|c|}
\hline \multirow[t]{2}{*}{ Determinants } & \multicolumn{2}{|c|}{$\begin{array}{c}\text { Un- } \\
\text { standardized } \\
\text { Coefficients }\end{array}$} & \multirow{2}{*}{\begin{tabular}{|c|}
$\begin{array}{c}\text { Standardized } \\
\text { Coefficients }\end{array}$ \\
Beta \\
\end{tabular}} & \multirow{2}{*}{$\begin{array}{l}\text { Significant } \\
\text { t- value }\end{array}$} & \multirow{2}{*}{$\begin{array}{c}\mathrm{P} \\
\text { value }\end{array}$} \\
\hline & $\mathrm{B}$ & $\begin{array}{l}\text { Std. } \\
\text { Error }\end{array}$ & & & \\
\hline Monthly income & .025 & .045 & .020 & .558 & .578 \\
\hline Shopping freely & .028 & .064 & -.024 & -.436 & .663 \\
\hline Small Purchase & .036 & .062 & .032 & .578 & .564 \\
\hline Large Purchase & -.018 & .028 & -.025 & -646 & .520 \\
\hline Maintenance of family expenditure & -.046 & .049 & .043 & .939 & .349 \\
\hline Land and Seedbed preparation & -.012 & .092 & .009 & .135 & .893 \\
\hline Sowing and planting transplanting & -.027 & .112 & -.020 & -.239 & .812 \\
\hline Harvesting and threshing crops & .064 & .084 & .046 & .762 & .448 \\
\hline Drying and preservation of Straws & .022 & .115 & .009 & .196 & .847 \\
\hline Fish culture & .111 & .075 & -.073 & -1.489 & .139 \\
\hline Business and handicraft production & .117 & .065 & .085 & 1.793 & .076 \\
\hline Equal consumption & -.009 & .041 & -.013 & -.227 & .821 \\
\hline Handling and spending money & -.063 & .050 & -.075 & -1.260 & .210 \\
\hline 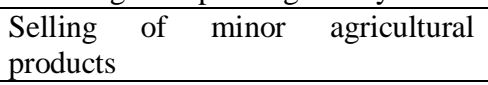 & .047 & .047 & .065 & 1.015 & .312 \\
\hline Scope at hiring helping hands & -.112 & .067 & -.133 & -1.670 & .098 \\
\hline Scope at utilization of credit money & .013 & .072 & .015 & .188 & .851 \\
\hline Scope of education & -.043 & .066 & -.046 & -.647 & .519 \\
\hline Scope of rural cooperative banks & -.127 & .052 & .175 & 2.451 & .016 \\
\hline Control own land and enjoy & .058 & .090 & .041 & .644 & .521 \\
\hline Control own cattle and enjoy & -.040 & .129 & -.029 & -.307 & .756 \\
\hline Own poultry and enjoy & -.246 & & .179 & 2.348 & .021 \\
\hline Own jewelry and enjoy & -.124 & .062 & -.087 & -1.989 & .049 \\
\hline Household loan spending & -.027 & .167 & $\begin{array}{l}.018 \\
\end{array}$ & -.162 & .872 \\
\hline Land or equipment selling decision & -.899 & & .516 & 4.313 & .000 \\
\hline Independent savings & -.722 & & -.511 & -8.838 & .000 \\
\hline Emergency fund access & -.049 & & -.035 & -.208 & .836 \\
\hline fund access through assets sales & -.257 & & -.151 & -1.214 & .227 \\
\hline Fund access from husband & .019 & & .013 & .072 & .942 \\
\hline fund access Husband relatives & .063 & & .042 & .379 & .705 \\
\hline fund access Own relatives & .182 & & .135 & 1.900 & .060 \\
\hline fund access Moneylenders & -.122 & & -.086 & -.432 & .666 \\
\hline fund access other people & .155 & 0.144 & .097 & 1.075 & .285 \\
\hline
\end{tabular}

Source: Field Survey, August- October, 2012

Coefficient analysis explained that the relationship between dependent variable and each independent variables. According to multiple regression, scope of rural cooperative banks, control of own poultry and its consumption, control of 
own jewelry and its enjoyment, land or equipment selling decision and independent savings have significantly influenced to women's economic empowerment. Here we have taken under consideration the significant variables only.

\section{CONCLUSIONS}

The study has measured the economic empowerment of the women who have received loan only from TMSS. Women economic empowerment has been taken as dependent variable whereas the factors of household and social resources of women, farm and non-farm activities, ownership of productive and nonproductive assets and role of women in economic issues have been considered as independent variables. The factors which have shown significantly associated with the women's economic empowerment are shopping freely, children dress, large purchase, maintenance of family expenditure, land and seedbed preparation, sowing planting transplanting, harvesting and threshing crops, drying and preservation of straws, livestock rearing, fish culture, poultry rearing, business and handicraft production, equal consumption, handling and spending money, selling of minor agricultural production, selling of minor agricultural products, scope for utilization of credit money, scope of education, scope for rural cooperative bank, control of own land and enjoy, control own cattle, goat and enjoy, control own poultry or cash savings and its enjoyment, control of own jewelry, household loans spending, land or equipment decision, land or equipment implementation, land or equipment spending, independent saving, emergency fund expense, fund access by assets sale, fund access from husband/relatives, fund access from money lenders, fund access from other people.

By estimating multiple regression we find that the factors of rural cooperative banks, control of own poultry, own jewelry, land or equipment selling decision, independent savings have significantly influenced women's economic empowerment. However, since the present study, due to its nature of both area and respondents selection, is not nationally representative and generalizable. There should be a study on larger scale. Despite the limitation of area and respondent selection, the present study claims that the study findings would be consistent with most of the areas in Bangladesh since the characteristics of the respondents and the peoples of the other regions are more or less homogenous. 


\section{REFERENCES}

Aminul Faraizi, Taskinur Rahman, Jim McAllister, 2010 "Microcredit and Women's Empowerment A Case Study of Bangladesh". Rout ledge Contemporary South Asian Series

BBS, 2006.Statistical Yearbook of Bangladesh.1st Edn., Bangladesh Bureau of Statistics, Statistics Division, Ministry of Planning, Govt. of the People's Republic of Bangladesh, Bangladesh.

Ferdoushi Ahmed et al., 2011"Impact of microcredit on poverty alleviation among rural women: A case study of Panchagarh District in Bangladesh" African Journal of Business Management Vol. 5(16), pp. 7111-7119, ISSN 1993-8233 @2011 Academic Journals

Goetz, A.M. and Sen Gupta, R. 1996"Who Takes the Credit? Gender, Power and Control Over Loan Use in Rural Credit Programmes in Bangladesh" World Development, Vol. 24, No. 1.

Hashemi, S.M. Schuler, S.R. and Riley, A.P. 1996 "Rural Credit Programs and Women's Empowerment in Bangladesh" World Development Vol. 24, No. 4.

Islam Md. Rafiqul 2011 “Rural Women's Empowerment through Self-income Generating Activities: A Study on NGOs Credit Programs in Bangladesh" Journal of Global Citizenship \& Equity Education, Vol 1, No 1

Kabeer, N. 2001Paid work, women's empowerment and gender justice: Critical pathways of social change. Pathways Working Paper 3. Brighton, UK: Pathways of Women's Empowerment Research Programme Consortium.

Kamal, G.M., Rahman, M.B. and Ghani, A.K.M.A. 1992 "Impact of Credit Program on Reproductive Behavior of Gramen Bank Women Beneficiaries" Associates for Community and Population Research, Dhaka.

MDG 2013 "Achieve full and productive employment and decent work for all, including women and young people", END POVERTY: Millennium Development Goals and Beyond 2015 
Pitt, M.M. and S.R. Khandker 1996. "Household and intra-household impact of the Gramen Bank and similar targeted credit programs in Bangladesh" World Bank Discussion Paper 320, USA: WS.

Shahnaj Parveen and Ingrid-Ute Leonhäuser 2004 "Empowerment of Rural Women in Bangladesh: A Household Level Analysis" Deutscher Tropentag- Berlin, 5-7 October 2004, Conference on Rural Poverty Reduction through Research for Development and Transformation

Yunus, M. (1991) "Gramen Bank: Experiences and Reflections"Conference on the Economic Advancement of Rural Women in Asia and the Pacific, held in Kuala Lumpur, Malaysia, 15-21 September, 1991. 


\section{APPENDIX- A}

TABLE 01

WOMEN'S ECONOMIC EMPOWERMENT THROUGH ACCESS OF HOUSEHOLD AND SOCIAL RESOURCES

\begin{tabular}{|c|c|c|c|c|c|c|c|c|}
\hline \multicolumn{9}{|c|}{ Frequency in percentage $(\mathrm{N}=152)$} \\
\hline \multirow{3}{*}{$\begin{array}{c}\text { Decisions } \\
\text { on children } \\
\text { education }\end{array}$} & Not at all & 2.0 & \multirow{3}{*}{$\begin{array}{l}\text { Own dress, } \\
\text { ornaments } \\
\text { without } \\
\text { consulting }\end{array}$} & Not at all & 27.0 & \multirow{3}{*}{$\begin{array}{l}\text { Budgeting } \\
\text { of family } \\
\text { expenses }\end{array}$} & Not at all & 7.2 \\
\hline & $\begin{array}{c}\text { To great } \\
\text { extent }\end{array}$ & 36.2 & & $\begin{array}{c}\text { To great } \\
\text { extent }\end{array}$ & 14.5 & & $\begin{array}{c}\text { To great } \\
\text { extent }\end{array}$ & 31.6 \\
\hline & $\begin{array}{c}\text { To some } \\
\text { extent }\end{array}$ & 61.8 & & $\begin{array}{c}\text { To some } \\
\text { extent }\end{array}$ & 58.6 & & $\begin{array}{c}\text { To some } \\
\text { extent }\end{array}$ & 61.2 \\
\hline \multirow{3}{*}{$\begin{array}{l}\text { Shopping } \\
\text { freely }\end{array}$} & Not at all & 5.3 & \multirow{3}{*}{$\begin{array}{l}\text { Ability to } \\
\text { spend own } \\
\text { income }\end{array}$} & Not at all & 9.2 & \multirow{3}{*}{$\begin{array}{c}\text { Small } \\
\text { Purchase }\end{array}$} & Not at all & 5.9 \\
\hline & $\begin{array}{l}\text { Great } \\
\text { extent }\end{array}$ & 28.9 & & $\begin{array}{l}\text { Great } \\
\text { extent }\end{array}$ & 15.8 & & $\begin{array}{l}\text { Great } \\
\text { extent }\end{array}$ & 49.3 \\
\hline & $\begin{array}{l}\text { Some } \\
\text { extent }\end{array}$ & 65.8 & & $\begin{array}{c}\text { To some } \\
\text { extent }\end{array}$ & 75.0 & & $\begin{array}{l}\text { Some } \\
\text { extent }\end{array}$ & 44.7 \\
\hline \multirow{3}{*}{$\begin{array}{l}\text { Children } \\
\text { dress }\end{array}$} & Not at all & 4.6 & \multirow{3}{*}{$\begin{array}{c}\text { Maintenance } \\
\text { of family } \\
\text { expenditure }\end{array}$} & Not at all & 8.6 & \multirow{3}{*}{$\begin{array}{c}\text { Spend } \\
\text { husband or } \\
\text { son income }\end{array}$} & Not at all & 16.4 \\
\hline & $\begin{array}{c}\text { To great } \\
\text { extent }\end{array}$ & 38.2 & & $\begin{array}{c}\text { To great } \\
\text { extent }\end{array}$ & 15.8 & & $\begin{array}{c}\text { To great } \\
\text { extent }\end{array}$ & 23.7 \\
\hline & $\begin{array}{c}\text { To some } \\
\text { extent }\end{array}$ & 57.2 & & $\begin{array}{c}\text { To some } \\
\text { extent }\end{array}$ & 75.7 & & $\begin{array}{c}\text { To some } \\
\text { extent }\end{array}$ & 59.9 \\
\hline
\end{tabular}

Source: Field Survey, August-October, 2012

TABLE 02

WOMEN'S ECONOMIC EMPOWERMENT THROUGH PARTICIPATION OF FARM AND NON-FARM ACTIVITIES

\begin{tabular}{|c|c|c|c|c|c|}
\hline \multicolumn{6}{|c|}{ Frequency in Percentage $(\mathrm{N}=152)$} \\
\hline \multirow{2}{*}{$\begin{array}{c}\text { Land and seedbed } \\
\text { preparation }\end{array}$} & Yes & 41.4 & \multirow{2}{*}{$\begin{array}{l}\text { Livestock } \\
\text { rearing }\end{array}$} & Yes & 86.2 \\
\hline & No & 58.6 & & No & 13.8 \\
\hline \multirow{2}{*}{$\begin{array}{l}\text { Sowing planting } \\
\text { transplanting }\end{array}$} & Yes & 51.3 & \multirow{2}{*}{ Poultry rearing } & Yes & 63.8 \\
\hline & No & 48.7 & & No & 36.2 \\
\hline \multirow{2}{*}{$\begin{array}{l}\text { Harvesting, } \\
\text { threshing crops }\end{array}$} & Yes & 62.5 & \multirow[t]{2}{*}{ Fishing culture } & Yes & 26.3 \\
\hline & No & 37.5 & & No & 73.7 \\
\hline \multirow{2}{*}{$\begin{array}{l}\text { Drying and } \\
\text { preservation of } \\
\text { straws }\end{array}$} & Yes & 92.8 & \multirow{2}{*}{$\begin{array}{c}\text { Business and } \\
\text { handicraft } \\
\text { production }\end{array}$} & Yes & 40.1 \\
\hline & No & 7.2 & & No & 59.9 \\
\hline \multirow{2}{*}{$\begin{array}{l}\text { Homestead } \\
\text { cultivation }\end{array}$} & Yes & 84.2 & & & \\
\hline & No & 15.8 & & & \\
\hline
\end{tabular}

Source: Field Survey, August- October, 2012 
TABLE 03

WOMEN'S ECONOMIC EMPOWERMENT IN TERMS OF PRODUCTIVE AND NON-PRODUCTIVE ASSETS

\begin{tabular}{|c|c|c|c|c|c|}
\hline \multicolumn{6}{|c|}{ Frequency in Percentage $(\mathrm{N}=152)$} \\
\hline \multirow{2}{*}{$\begin{array}{l}\text { Control own land } \\
\text { and enjoy }\end{array}$} & Yes & 36.2 & \multirow{2}{*}{$\begin{array}{l}\text { Control own jewelry } \\
\text { and enjoy }\end{array}$} & Yes & 34.2 \\
\hline & No & 63.8 & & No & 65.8 \\
\hline \multirow{2}{*}{$\begin{array}{l}\text { Control own cattle } \\
\text { or goat and enjoy }\end{array}$} & Yes & 46.1 & \multirow{2}{*}{$\begin{array}{l}\text { Control own } \\
\text { television or radio } \\
\text { and enjoy }\end{array}$} & Yes & 24.3 \\
\hline & No & 53.9 & & No & 75.7 \\
\hline \multirow{2}{*}{$\begin{array}{l}\text { Control own poultry } \\
\text { or cash savings and } \\
\text { enjoy }\end{array}$} & Yes & 40.8 & \multirow{2}{*}{$\begin{array}{l}\text { Control own small } \\
\text { vehicle and enjoy }\end{array}$} & Yes & 16.4 \\
\hline & No & 59.2 & & No & 83.6 \\
\hline
\end{tabular}

Source: Field Survey, August- October, 2012

TABLE 04

WOMEN'S ECONOMIC EMPOWERMENT IN TERMS OF EQUITABLE CONSUMPTION, MONEY UTILIZATION, SCOPE OF EDUCATION

\begin{tabular}{|c|c|c|c|c|c|}
\hline \multicolumn{6}{|c|}{ Frequency in percentage $(\mathrm{N}=152)$} \\
\hline \multirow{4}{*}{$\begin{array}{c}\text { Equal } \\
\text { consumpti } \\
\text { on }\end{array}$} & No access & 7.9 & \multirow{4}{*}{$\begin{array}{l}\text { Scope } \\
\text { utilization of } \\
\text { credit money }\end{array}$} & No access & 13.2 \\
\hline & Low access & 17.1 & & Low access & 36.2 \\
\hline & $\begin{array}{l}\text { Medium } \\
\text { access }\end{array}$ & 27.6 & & $\begin{array}{l}\text { Medium } \\
\text { access }\end{array}$ & 46.1 \\
\hline & High access & 47.4 & & High access & 4.6 \\
\hline \multirow{4}{*}{$\begin{array}{l}\text { Handling } \\
\text { and } \\
\text { spending } \\
\text { money }\end{array}$} & No access & 14.5 & \multirow{4}{*}{$\begin{array}{l}\text { Scope } \\
\text { education }\end{array}$} & No access & 10.5 \\
\hline & Low access & 33.6 & & Low access & 40.1 \\
\hline & $\begin{array}{l}\text { Medium } \\
\text { access }\end{array}$ & 46.7 & & $\begin{array}{l}\text { Medium } \\
\text { access }\end{array}$ & 45.4 \\
\hline & High access & 5.3 & & High access & 3.9 \\
\hline \multirow{4}{*}{$\begin{array}{l}\text { Selling of } \\
\text { minor } \\
\text { expenditur } \\
\text { e products }\end{array}$} & No access & 44.1 & \multirow{4}{*}{$\begin{array}{l}\text { Scope rural } \\
\text { cooperative and } \\
\text { bank }\end{array}$} & No access & 14.5 \\
\hline & Low access & 15.8 & & Low access & 36.2 \\
\hline & $\begin{array}{l}\text { Medium } \\
\text { access }\end{array}$ & 39.5 & & $\begin{array}{l}\text { Medium } \\
\text { access }\end{array}$ & 32.9 \\
\hline & High access & .7 & & High access & 16.4 \\
\hline \multirow{4}{*}{$\begin{array}{l}\text { Scope at } \\
\text { hiring of } \\
\text { helping } \\
\text { hands }\end{array}$} & No access & 15.8 & & & \\
\hline & Low access & 27.6 & & & \\
\hline & $\begin{array}{l}\text { Medium } \\
\text { access }\end{array}$ & 52.6 & & & \\
\hline & High access & 3.9 & & & \\
\hline
\end{tabular}

Source: Field Survey, August-October, 2012 
TABLE 05

WOMEN'S ECONOMIC EMPOWERMENT THROUGH DECISIONS

REGARDING ECONOMIC SPHERES

\begin{tabular}{|c|c|c|c|c|c|}
\hline \multicolumn{6}{|c|}{ Frequency in percentage $(\mathrm{N}=152)$} \\
\hline \multirow{2}{*}{$\begin{array}{l}\text { House hold loans } \\
\text { spending }\end{array}$} & Yes & 29.6 & \multirow{2}{*}{$\begin{array}{l}\text { Fund access } \\
\text { asset sale }\end{array}$} & Yes & 19.3 \\
\hline & No & 70.4 & & No & 80.3 \\
\hline \multirow[b]{2}{*}{$\begin{array}{l}\text { Land or equipment } \\
\text { decision }\end{array}$} & $\begin{array}{l}\text { Husband } \\
\text { alone }\end{array}$ & 81.6 & \multirow[b]{2}{*}{$\begin{array}{l}\text { Fund access } \\
\text { from husband }\end{array}$} & Yes & 32.9 \\
\hline & Together & 18.4 & & No & 67.1 \\
\hline \multirow{2}{*}{$\begin{array}{l}\text { Land or equipment } \\
\text { implementation }\end{array}$} & Yes & 33.6 & \multirow{2}{*}{$\begin{array}{l}\text { Fund access } \\
\text { husband } \\
\text { relatives }\end{array}$} & Yes & 27.6 \\
\hline & No & 66.4 & & No & 72.4 \\
\hline \multirow{2}{*}{$\begin{array}{l}\text { Land or equipment } \\
\text { spending }\end{array}$} & Yes & 35.5 & \multirow{2}{*}{$\begin{array}{l}\text { Fund access } \\
\text { own relatives }\end{array}$} & Yes & 51.3 \\
\hline & No & 64.5 & & No & 48.7 \\
\hline \multirow{2}{*}{$\begin{array}{l}\text { Independent } \\
\text { saving and control } \\
\text { of wife }\end{array}$} & Yes & 35.5 & \multirow{2}{*}{$\begin{array}{l}\text { Fund access } \\
\text { money } \\
\text { lenders }\end{array}$} & Yes & 34.9 \\
\hline & No & 64.5 & & No & 65.1 \\
\hline \multirow{2}{*}{$\begin{array}{l}\text { Emergency fund } \\
\text { expense }\end{array}$} & Yes & 36.2 & \multirow{2}{*}{$\begin{array}{l}\text { Fund access } \\
\text { other people }\end{array}$} & Yes & 23.7 \\
\hline & No & 63.8 & & No & 76.3 \\
\hline
\end{tabular}

Source: Field Survey, August- October, 2012 


\section{APPENDIX: B}

TABLE 06

\section{SUMMERY TABLE OF CRAMER'S V VALUES ON WOMEN ECONOMIC} EMPOWERMENT BY SOCIO DEMOGRAPHIC FACTORS

\begin{tabular}{|l|l|}
\hline Socio demographic Factors & Women empowerment \\
\hline Age & Cramer's V=0 .330* \\
\hline Occupation & Cramer's V $=0.213^{*}$ \\
\hline Monthly Income & Cramer's V $=0.330^{*}$ \\
\hline Religion & Cramer's V $=0.228^{*}$ \\
\hline Education & Cramer's V $=.236^{*}$ \\
\hline $\begin{array}{l}\text { For the nominal level variables, Cremer's V (for larger than } \\
2 \times 2 \text { cross table) and Phi (for } 2 \times 2 \text { cross table) tests are used } \\
* \text { Significance at } 0.01 \text { level }\end{array}$ \\
\hline
\end{tabular}

Source: Field Survey, August- October, 2012

TABLE 07

SUMMERY TABLE OF CRAMER'S V VALUES CONCERNING HOUSEHOLD AND SOCIAL RESOURCES WITH WOMEN'S ECONOMIC EMPOWERMENT

\begin{tabular}{|c|c|c|l|}
\hline $\begin{array}{l}\text { Household and } \\
\text { community level } \\
\text { activities }\end{array}$ & $\begin{array}{c}\text { Values of political } \\
\text { empowerment }\end{array}$ & $\begin{array}{c}\text { Household and } \\
\text { community level } \\
\text { activities }\end{array}$ & $\begin{array}{l}\text { Values of } \\
\text { political } \\
\text { empowerment }\end{array}$ \\
\hline $\begin{array}{c}\text { Decisions on } \\
\text { children education }\end{array}$ & Cramer's V=.161 & Large purchase & $\begin{array}{l}\text { Cramer's } \\
\text { V=.216* }\end{array}$ \\
\hline Shopping freely & Cramer's V=.224* & $\begin{array}{c}\text { Own dress or } \\
\text { ornaments without } \\
\text { consulting husband }\end{array}$ & $\begin{array}{l}\text { Cramer's } \\
\text { V=.170 }\end{array}$ \\
\hline Children dress & $\begin{array}{c}\text { Cramer's } \\
\text { V=.183** }\end{array}$ & $\begin{array}{c}\text { Ability to spend } \\
\text { own income }\end{array}$ & $\begin{array}{l}\text { Cramer's } \\
\text { V=.161 }\end{array}$ \\
\hline $\begin{array}{c}\text { Budgeting on } \\
\text { family expense }\end{array}$ & Cramer's V=.149 & $\begin{array}{c}\text { Maintenance of } \\
\text { family expenditure }\end{array}$ & $\begin{array}{l}\text { Cramer's } \\
\text { V=.196** }\end{array}$ \\
\hline Small purchase & Cramer's V=.212* & $\begin{array}{c}\text { Spend husband or } \\
\text { son income }\end{array}$ & $\begin{array}{l}\text { Cramer's } \\
\text { V=.117 }\end{array}$ \\
\hline * Significance at 0.01 & level , ** significance at 0.05 level \\
\hline
\end{tabular}

Source: Field Survey, August- October, 2012 
TABLE 08

SUMMERY TABLE OF PHI VALUES CONCERNING FARMING AND NONFARMING ACTIVITIES AND WOMEN'S ECONOMIC EMPOWERMENT

\begin{tabular}{|c|c|c|c|}
\hline $\begin{array}{c}\text { Farming and non- } \\
\text { farming activities }\end{array}$ & $\begin{array}{c}\text { Values of } \\
\text { economic } \\
\text { empowerment }\end{array}$ & $\begin{array}{c}\text { Farming and non- } \\
\text { farming activities }\end{array}$ & $\begin{array}{c}\text { Values of } \\
\text { economic } \\
\text { empowerment }\end{array}$ \\
\hline $\begin{array}{c}\text { Land and seedbed } \\
\text { preparation }\end{array}$ & Phi=.535* & Livestock rearing & Phi=.203** \\
\hline $\begin{array}{c}\text { Sowing planting } \\
\text { transplanting }\end{array}$ & Phi=.411* & Poultry rearing & Phi=.217** \\
\hline $\begin{array}{c}\text { Harvesting and } \\
\text { threshing crops }\end{array}$ & Phi $=.333^{*}$ & Fish culture & Phi=.517* \\
\hline $\begin{array}{c}\text { Drying and } \\
\text { preservation of } \\
\text { straws }\end{array}$ & Phi $=.233^{*}$ & $\begin{array}{c}\text { Business and } \\
\text { handicraft } \\
\text { production }\end{array}$ & Phi=.313* \\
\hline $\begin{array}{c}\text { Home stead } \\
\text { cultivation }\end{array}$ & Phi=.133 & \\
\hline Significance at 0.01 & level and ** significance at 0.05 level \\
\hline
\end{tabular}

Source: Field Survey, August- October, 2012

TABLE 09

SUMMERY TABLE OF CRAMER'S V VALUES CONCERNING THE
OWNERSHIP OF PRODUCTIVE AND NON-PRODUCTIVE ASSETS

\begin{tabular}{|c|c|l|c|}
\hline $\begin{array}{l}\text { Productive and non- } \\
\text { productive assets }\end{array}$ & $\begin{array}{l}\text { Values of } \\
\text { economic } \\
\text { empowerment }\end{array}$ & $\begin{array}{l}\text { Productive and } \\
\text { non-productive } \\
\text { assets }\end{array}$ & $\begin{array}{l}\text { Values of } \\
\text { economic } \\
\text { empowerment }\end{array}$ \\
\hline Equal consumption & $\begin{array}{l}\text { Cramer's } \\
\text { V=.318* }\end{array}$ & $\begin{array}{l}\text { Scope utilization of } \\
\text { credit money }\end{array}$ & $\begin{array}{c}\text { Cramer's } \\
\text { V=.293* }\end{array}$ \\
\hline $\begin{array}{c}\text { Handling and } \\
\text { spending money }\end{array}$ & $\begin{array}{l}\text { Cramer's } \\
\text { V=.294* }\end{array}$ & Scope of education & $\begin{array}{c}\text { Cramer's } \\
\text { V=.322* }\end{array}$ \\
\hline $\begin{array}{c}\text { Selling of minor } \\
\text { agricultural products }\end{array}$ & $\begin{array}{l}\text { Cramer's } \\
\text { V=.380* }\end{array}$ & $\begin{array}{c}\text { Scope rural } \\
\text { cooperative bank }\end{array}$ & $\begin{array}{c}\text { Cramer's } \\
\text { V=.373* }\end{array}$ \\
\hline $\begin{array}{c}\text { Selling of minor } \\
\text { agricultural products }\end{array}$ & $\begin{array}{c}\text { Cramer's } \\
\text { V=.286* }\end{array}$ & \multicolumn{2}{|c|}{ * Significance at 0.01 level } \\
\hline
\end{tabular}

Source: Field Survey, August- October, 2012 
TABLE 10

\section{SUMMERY TABLE OF PHI VALUES CONCERNING ECONOMIC EMPOWERMENT THROUGH DECISIONS REGARDING ECONOMIC SPHERES}

\begin{tabular}{|c|c|c|c|}
\hline $\begin{array}{l}\text { Household and community } \\
\text { level activities }\end{array}$ & $\begin{array}{l}\text { Values of } \\
\text { political } \\
\text { empowerment }\end{array}$ & $\begin{array}{l}\text { Household and } \\
\text { community level } \\
\text { activities }\end{array}$ & $\begin{array}{l}\text { Values of } \\
\text { political } \\
\text { empowerment }\end{array}$ \\
\hline Household loans expending & Phi $=.710^{*}$ & $\begin{array}{c}\text { Fund access by assets } \\
\text { sale }\end{array}$ & Phi $=.858^{*}$ \\
\hline Land or equipment decision & Phi $=.892 *$ & $\begin{array}{c}\text { Fund access from } \\
\text { husband }\end{array}$ & Phi=-.691* \\
\hline $\begin{array}{l}\text { Land or equipment } \\
\text { implementation }\end{array}$ & $\mathrm{Phi}=.689^{*}$ & $\begin{array}{l}\text { Fund access from } \\
\text { husband relatives }\end{array}$ & Phi $=.727 *$ \\
\hline $\begin{array}{l}\text { Land or equipment } \\
\text { spending }\end{array}$ & Phi $=.686^{*}$ & $\begin{array}{c}\text { Fund access from own } \\
\text { relatives }\end{array}$ & $\mathrm{Phi}=.766^{*}$ \\
\hline $\begin{array}{l}\text { Independent saving and } \\
\text { control of wife }\end{array}$ & Phi $=-.943^{*}$ & $\begin{array}{c}\text { Fund access from } \\
\text { money lenders }\end{array}$ & Phi $=.685^{*}$ \\
\hline Emergency fund expense & Phi $=.684^{*}$ & $\begin{array}{l}\text { Fund access from other } \\
\text { people }\end{array}$ & Phi $=.779 *$ \\
\hline
\end{tabular}

Source: Field Survey, August- October, 2012 